\title{
DQE/CE/155/7-T6
}

Final Technical Report

for

\section{Instrumentation of Dynamic Gas Pulse Loading System}

\author{
Grant Number DE-FG01-91CE15517 \\ Grant Duration $9 / 19 / 91$ - 3/18/93
}

submitted to:

Glenn Ellls, Project Offlcer

CE-521, (202)586-1507

U.S. DOE 1000 Independence Avenue, S.W.

Washington, D.C. 20535

on

July 31. 1993

by

Henry Mohaupt. President

Servo-Dynamles inc.

P.O. Box 6679

Santa Barbara, CA 93160

(805) 569-5885
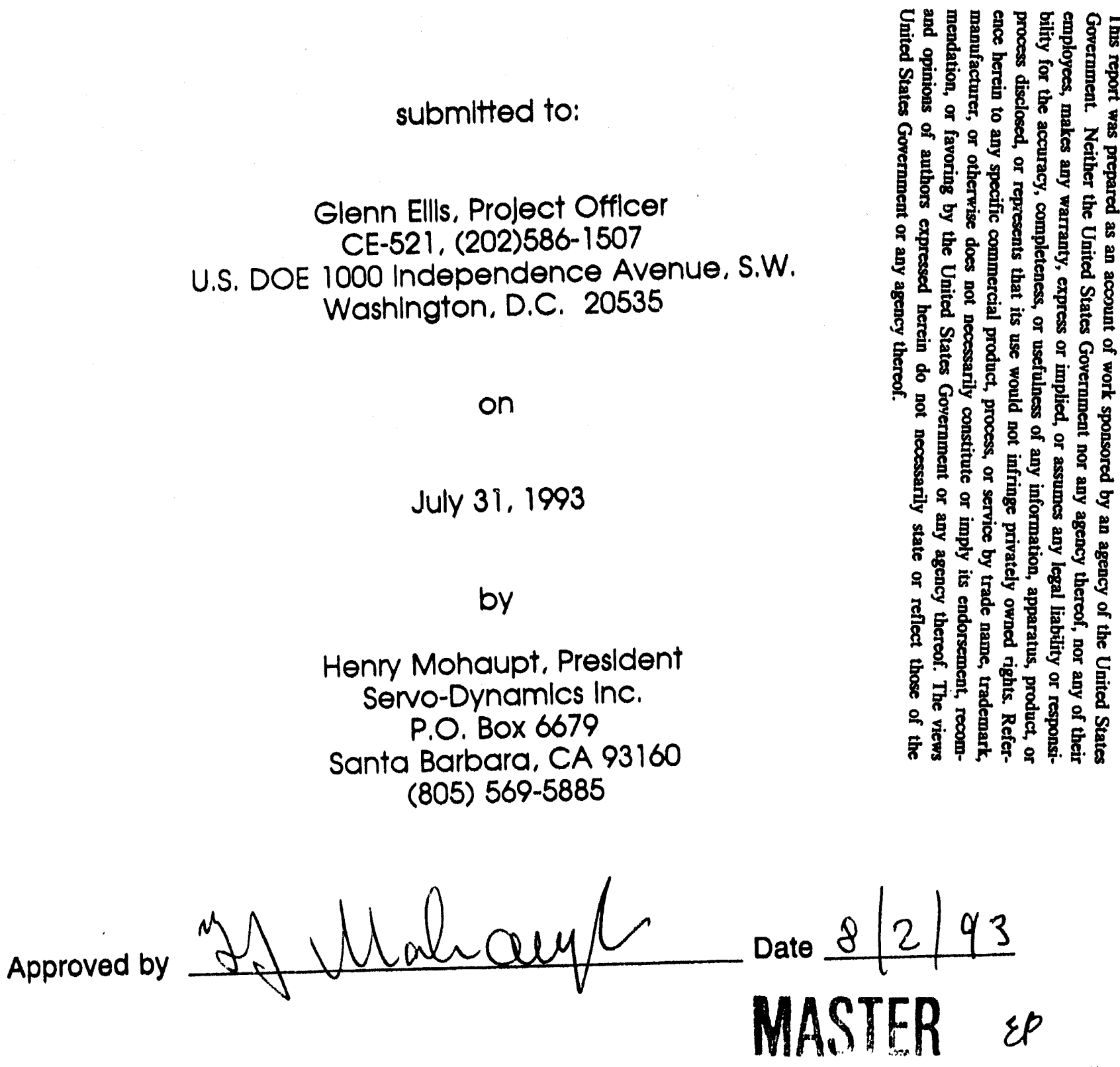


\section{Contents}

1. Introduction and Summary

a. Introduction to Stressfrac DGPL stimulation

b. Project Description (DOE application appendix A)

c. Summary of Results

d. Conclusions

e. Commercial Outlook and Future Plans for DGPL development

2. The FRAC Computer Model of the DGPL Process

a. Physical Basis of the Model

b. Applications of the Model

3. Digital Data Recording Systems

a. Digitizers and Computer Hardware

b. Software Design and Operation

4. Laboratory Cascade Chamber Studies

a. Differential Pressure Chamber Concept

b. Plezoelectric Sensor Technology

c. Cascade Chamber Data

5. Maricopa Field Studles

a. Test Site Facilities

b. Burn Rate Studies

6. Downhole Pressure Measurement Techniques

a. Wirellne with Pressure or Contact Ignition

b. Wireline with Electrical Ignition

c. Downhole recording systems

7. Acoustlc and Seismlc Measurements

a. Sensors and Recording Equlpment

b. Acoustic and Selsmic Data 


\section{Introduction and Summary}

\section{1-a. Introduction to Stressfrac DGPL stimulation}

The Dynamic Gas Pulse Loading (DGPL) process is an hydraulic fracturing method which uses $\mathrm{CO}_{2}$ and $\mathrm{CO}$ gas as a working fluld instead of a liquld. The DGPL system can be used to generate fractures for horizontal and vertical oll and gas well completions in both open hole and perforated casing. The DGPL system provides a cost effective tool for repalring near well bore permeability damage caused by inappropriate chemical treatment, migrating fines and paraffins, or slotted liners blocked by sand. Because the gas is generated from a solld propellant materlal by chemical reaction, no heavy equipment is required. Tremendous pump rates can be obtained. Peak pressures are naturally locallized at the tool position by the tamping effect of well fluids. Thus many of the leakage and sealing problems which plague static hydrofrac processes are completely avoided. DGPL may be effectively used before acid treatment to provide fresh pathways for the acid to reach the formation. The smaller tools may be positioned by wirelline, though most Stressfrac tools are tubing conveyed.

An example of a relatlvely large Stressfrac stimulation is the South Mountain job plctured below in Figures 1-1, 1-2 and 1-3, where 2.375 inch dlameter propellant tools were mounted in 12 foot lengths of perforated tubing. Five 12 foot sections were joined on the ground to form 60 foot long tool carriers. Fourteen of the 60 foot lengths were lifted one at a time and joined at the well head to make an 830 foot long tool which was positioned between 3810 and $4640 \mathrm{ft}$ depth. The stimulation was carried out under oll.

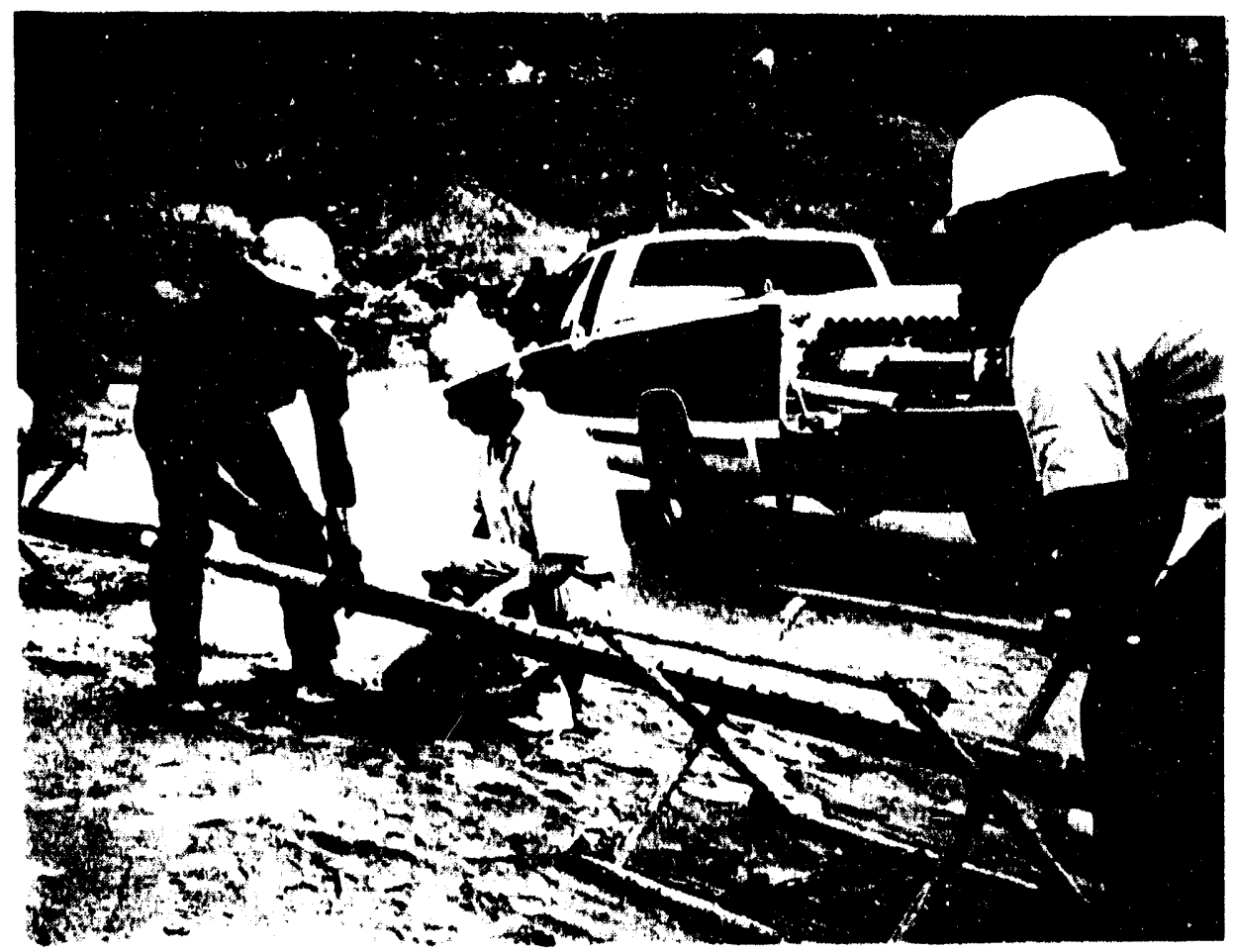

Figure 1-1 Stressfrac propellant tools carried to the site by pickup truck are assembled into 60 foot long tool carriers on the ground. 


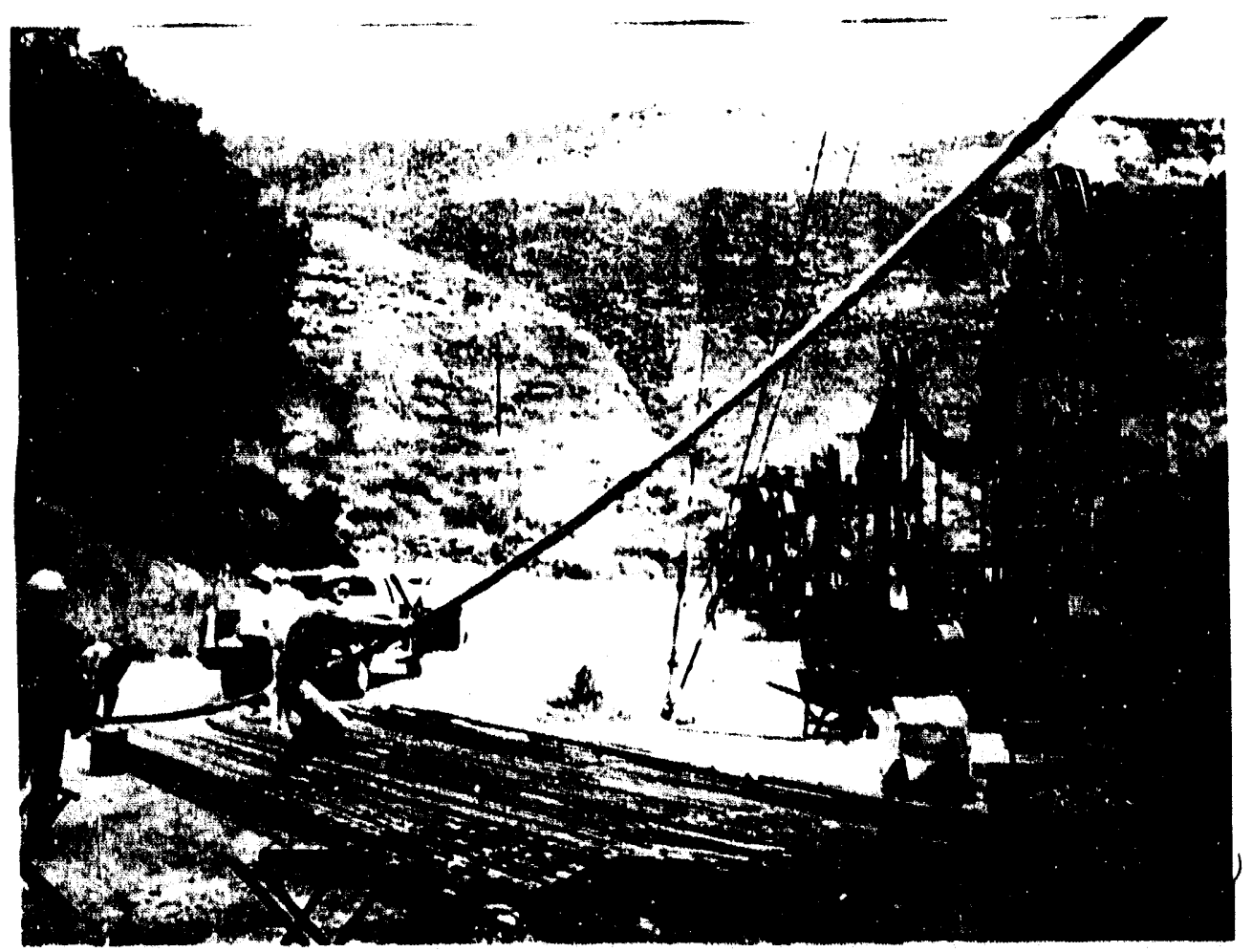

Figure 1-2 Sixty foot long Stressfrac tool carriers are ploked up one at a time.

Figure 1-3 The sixty foot long tool carriers are joined at the wellhead into an 830 foot long tool and lowered 4,000 feet.

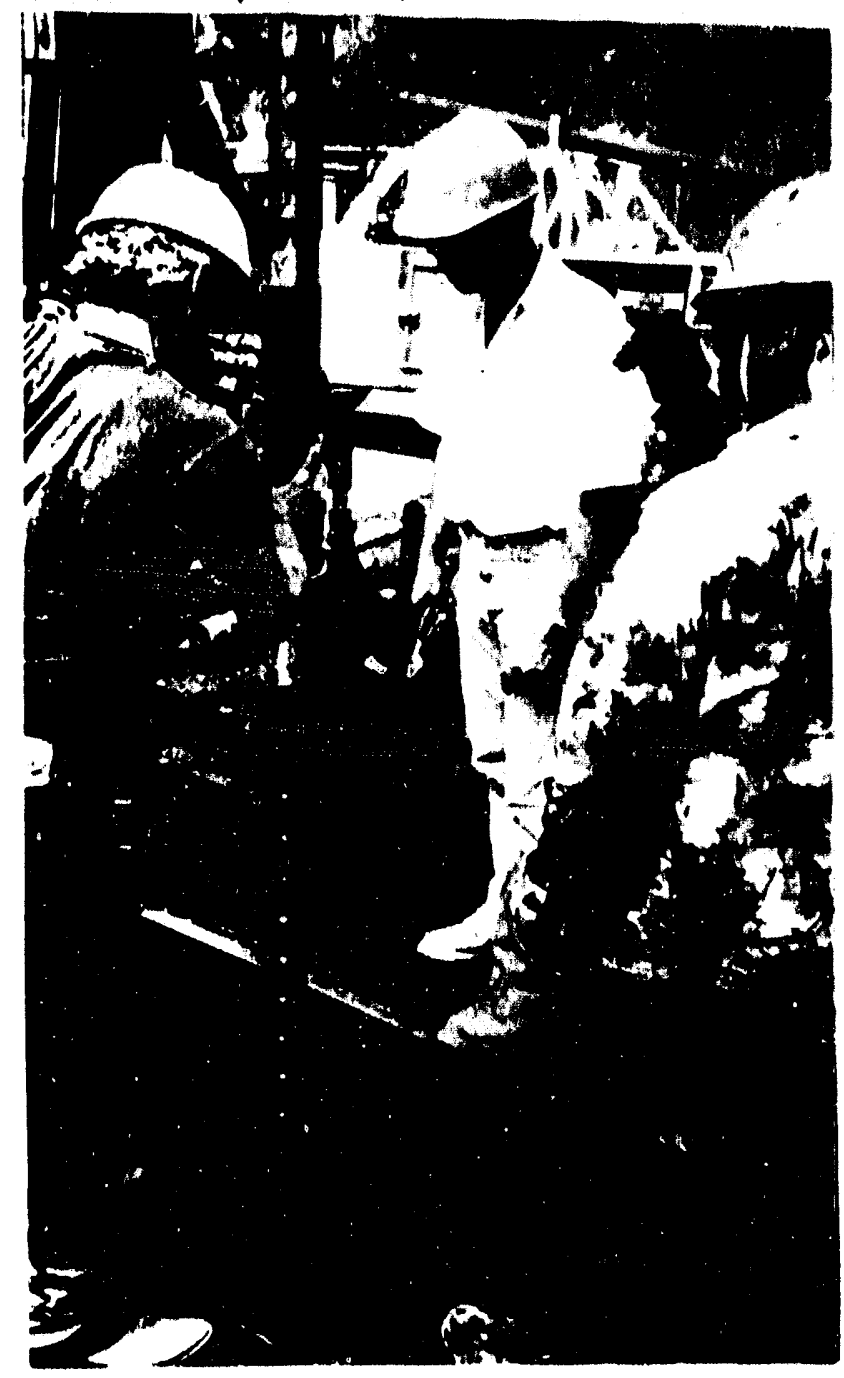




\section{1-b. Project Descriptlon (DOE grant appllcation appendlx A)}

The overall goal of this work is to further develop and fleld test a system of stimulating oll and gas wells, which increases the iffectlve radius of the well bore so that more oll can flow into it, by recording pressure during the gas generatlon phase in real time so that fractures can be induced more predictably in the producing formation.

Task 1. Complete the laboratory studles currently underway with the prototype model of the instrumentation currently being studied.

Task 2. Perform fleld tests of the model in the Tatt/Bakersfleld area, utllizing operations closest to the engineers working on the project, and optimize the unit for varlous condlitions encountered there.

Task 3. Perform fleld test of the model In DGPL Jobs which are scheduled in the midcontinent area, and optimize the unit for downhole conditions encountered there.

Task 4. Analyze and summarize the results achleved during the complete test serles, documenting the steps for usage of downhole Instrumentation in the fleld, and complle data specifying use of the technology by others.

Task 5. Prepare final report for DOE, and Include also a report on the fleld tests completed. Describe and estimate the probability of the technology beling commerclallzed and in what time span. 


\section{1-c. Summary of Results}

The major achlevements under this grant program were:

1. Laboratory scale studles of the pressure differential between the inside and outside of perforated well casing during Stressfrac DGPL stimulation.

2. Development of a practlcal computer model for Stressfrac DGPL stimulation which takes Into account the effects of tool size, fracture gradient, statlo pressure, casing size, well fluld, and temperature to compute the fracture volume and estimate fracture lengths.

3. Development of an Improved laboratory digital data recording system capable of recording up to elght data channels simultaneously. Sampling rates of 40,000 samples per second were obtained on each of three analog signals and a digltal port. Techniques for the use of plezoelectric pressure sensors were Improved.

4. Development of a compact version of the digltal data recording system for fleld use at the surface, with a portable generator system.

5. Large scale tests of Stresstrac DGPL pressure generators at our Marlcopa fleld test site, using the portable digltal data recording system. Important bum rate studles were begun. Video recording was used to obtain addltional data.

6. Initlal investlgation of battery powered downhole pressure recorder designs.

7. Initial exploration of sonic and selsmic recording of Stressfrac DGPL stimulations on wells In Callfornia and North Dakota. These new techniques provide a promising new source of information about Stressfrac pressure generation and fracture growth.

The Stressfrac DGPL stimulation process has been in commercial use for a number of years. The computer programs, research data and instrumentation systems developed under thls grant contributed to a better understanding of the process and have been incorporated in commerclal operations.

\section{1-d. Concluslons}

Stressfrac DGPL stimulation has been a valued tool of the oll industry for twenty years. During thie past five years technical developments have greatly extended the range of stimulation projects that can be handled by this flexlble system. Stressfrac DGPL stimulation has an Important role to play in economically maintaining production of aging oll flelds, and in Improving the rate of production and extraction efficiency of new gas and oll reserves. Continued technical development of this process will repay the nation many times over. However, because of the present financlal and operational uncertaintles in the oll Industry, the Stressfrac DGPL process is not currently being widely applied and its potentlal benefits are being lost. 


\section{1-0. Future Plans for DGPL development}

There are saveral new ldeas which have emerged during the course of this project. We plan to submit them to NIST for consideration under the Energy Related Inventlons Program and directly to the DOE for possible demonstration program funding.

1. Recent work by others In the Michlgan Antrim Shale has emphasized the problem of fracturing relatively soft shale formations. If the formation plastically deforms like clay under pressure it is difficult to Initiate a fracture. We feel that maintaining a slow rise time of the pressure pulse is a critical factor in such formations. A new varlation of the STRESSFRAC system is under development for this application. If successful, this approach could be a key element in the economical production of large natural gas reserves.

2. Another area of development is the perforation and breakdown of limited entry Injection wells. The effective and uniform breakdown of each perforation tunnel is critical In establishing control of the injection profile, and thereby efficlently producing the reservolr. A new approach to this problem has been designed which promises to be both economical and effective.

3. The selsmic measurement of the fracture productlon process during Dynamic Gas Pulse Loading stimulation is an entirely new area which was initlated under the present study. The very prellminary data obtained thus far suggests that this measurement can be of signiflcant value in evaluating the effect of DGPL stimulation. The selsmic signals provide a direct link to fractures as they are formed and offer new insight into the fracture process. 


\section{The FRAC Computer Model of the DGPL Process}

Engineering practice for DGPL stimulations ls based on years of experlence. In addition to the technical detalls of assembly, Installation, Ignition, and tool removal, there are basic physical laws which govern the operation of the tool. The FRAC computer model was developed under this DOE supported project to compute the effect of these physical effects to gulde the DGPL project engineer.

\section{2-a. Physlcal Basle of tho Model}

The DGPL system is a gas generator. As fractures form they expand to a maximum volume, and then close again as the gas cools and is forced back into the well. The maximum extent of the fracture network is reached when the gas is relatively cool and motionless, in equillbrlum with the pressure exerted by the fractured formation. Thus the FRAC program is based on the thermodynamle law for gas in equillbrlum: $V=N K T / P$ (volume is proportional to the number of molecules times the temperature divided by the pressure). Since $\mathrm{N}$ is proportional to the solld volume of the tool we can write this as:

$$
V=K_{2} V_{1001} T / P \text {. }
$$

The volume of propellant is calculated from the length and dlameter of the tool, the temperature is calculated by assuming a $3 \%$ heat retention in the gas after expansion and contact with the fracture walls, and adding the resulting temperature to the ambient temperature of the formation. The "closure pressure" that the fracture walls exert on the gas is determined by the hydraullc fracture gradient, measured In the well or typloal of the formation, typlcally $0.7 \mathrm{psi} / \mathrm{tt}$. Thls "equillibrium model" determines the total volume of the gas which may be several thousand liters for a large tool at shallow depth, or only a few dozen llters for a moderate tool at great depth.

The well fluld serves as a "tamp" for the gas, preventing it from escaping up the well casing. Usually there is fluld both above and below the tool which is compressed sllghtly by the gas pressure. The outer boundary of the compressed region moves at the speed of sound in the fluld column. If the tool is at the bottom of the well only the one column of fluld above the tool is compressed. The compressed fluld moves at a velocity, $v_{1}$ of a few meters per second according to a simple lavi derived from the conservation of momentum, mass times velocity equals force times time. This velocity, $v$, is also the velocity of the gas-fluld interface, and ls used to compute the volume of the gas retained Inside the casing.

$$
\mathrm{Mv}=\mathrm{Ft}
$$

Consider a cyllinder of fluld of length of where $c$ is the speed of sound and t the time, in a casing of cross sectional area $A$. The fluld density is $p$, and 80 the mass $M=p c t A$. The net force $F$, on the moving cyllnder of fluld is the cross sectional area $A=\pi D^{2} / 4$ IImes the difference between the gas pressure $\mathrm{P}$ and the original static hydraulic pressure $P_{0}$. The momentum equation is then:

canceling $A$ and $t$,

$$
\begin{gathered}
M V=\operatorname{pctAV}=\left(P \cdot P_{0}\right) A t \\
\operatorname{pCV}=\left(P \cdot P_{0}\right)
\end{gathered}
$$


80 the velocity of one moving fluld column is given by

$$
V=\left(P-P_{0}\right) / \rho c .
$$

As the fluld moves away from the gas pressure it leaves an open space for the gas to occupy. Assuming the tool is not at the bottom of the well, there are two open spaces produced, one above and one below the tool.

The volume of gas in the casing, $V_{0}$, is then:

$$
V_{0}=V_{\text {rool }}+2 A V t=V_{\text {bod }}+2\left(A\left(P_{\cdot} \cdot P_{0}\right) / \rho c\right.
$$

The volume of gas forced into the formation to produce fractures, $V_{11}$ le:

or

$$
V_{1}=V \cdot V_{0}=K_{2} V_{\text {bool }} T / P-V_{\text {bool }}-2 L A\left(P-P_{0}\right) / \rho C
$$

$$
V_{1}=V_{\text {bool }}\left(K_{2} T / P-1\right) \cdot 2\left(A\left(P \cdot P_{0}\right) / P C\right.
$$

This relationship shows how the equilibrium fracture volume depends on the tool size, gas temperature, casing dlameter, hydrostatlc pressure, closure pressure, fluld density, the speed of sound in the fluld, and the gas generation time of the tool. Though this model ignores subtletles such as gas dynamics, in sltu stress, fracture propagation, and formation porosity it does provide a consistent engineering estimate of fracture volume bused on sound englneering data.

\section{Poak Preseure In the Absence of Fraotures}

Note that if $V_{1}$ were constrained to bJ zero, as by the accidental absence of perforations or a section of unusually strong rock, the resulting peak pressure, $P_{\text {max }}$, can be calculated from the quadratlc equatlon obtained by multiplying through with $P_{\max }$ :

$$
P_{\max } " V_{1}=0=V_{\text {bool }}\left(K_{2} T \cdot P_{\max }\right)-2 t A\left(P_{\max }^{2}-P_{\max } P_{0}\right) / p c
$$

If the pressure is well above the hydrostatlc pressure we can get a simple approximate solution by lgnoring the linear terms in $P_{\max }$. Thls approximate solution shows the effect of tool size, gas generation ilme, cross sectional area and fluld propertles on the maximum pressure with fluld tamping:

$$
P_{\max }=\left[V_{\text {book }} K_{2} T \rho c / 2 t A\right]^{0.6}
$$

The exact quadratic solution is easlly evaluated also, though less intuitive. Typical maximum peak pressures are around $20,000 \mathrm{psl}$.

In practlce sensible design of the tool provides a gas generation time $t$, that is long enough to allow the fluld to move cut of the way at reasonable pressures that will not damage the casing. It is clear that if the gas generation time, $t$, of the tool is too short, 
the "safety valve" effect of the tamping fluld lo lost. As t approaches zero as it does in an explosive, the gas is confined to the origina! tool volume and the peak pressure le very high. Simllarly, a very large dlameter casing (large A) greatly Increases the gas volume Inside the casing, and leaves less gas for the fractures. Note that the volume lost to fluld motion drops to zero if the initial hydrostatic pressure $P_{0}$ equals the closure pressure $P$ of the formation. In that case the fluld pressure itself is ready to fracture the formation.

To estimate the effect of fractures on well production it is important to know the length of the fractures. In a simple flow model, the effectlve wellbore radius is the fracture radlus. In formations with low permeability the rate of production is greatly increased by fractures extending tens of feet around a six inch well bore. In older wells, the migration of fines produce a skin around the wellbore that reduces flow, and fractures of even a few Inches can make a great Improvement in production.

The calculation of fracture radlus from the fracture volume requires some geometrlc assumptions. Accurate calculation oi fracture dimensions from first princlples can be done for well characterlzed materials, but the necessary physical parameters are seldom avallable for a practical oll producing well. Any pre-exlsting fracture network can play an Important role is the growth of fractures. Inhomogenelties and stresses in the formation also play an important role.

To present the computed fracture volume in an easlly understood form as an average fracture radius, the following assumptions are made about fracture geometry: The fractures are rectangular wings of width equal to the fracture radlus radlating out from the wellbore. The length of the rectangle is equal to the tool length plus $30 \%$ of the fracture radlus at each end. In open holes the number of ivings can be estlmated from the pressure rise time vs sound propagation time around the circumference of the wellbore. However, mine back studles show that in perforated casing, the initlal fractures are aligned with the perforation pattern and the fractures which follow the natural stress Induced fractures in the formation grow to be dominant. Normally two dominant fracture wings are assumed. The average width of the fractures at the equilibrlum displacement is assumed to be 0.5 to 1 millimeter. Thls gives a fracture radius consistent with mineback studles carried out by Sandla Natlonal Laboratorles in ash fall tuff. The actual fracture radius will vary along the length of the tool, reaching further out at some points and less at others in response to the natural varlations in the formation.

\section{2-b. Appllcations of the Model}

The FRAC program has proven to be a useful gulde in the design of DGPL stimulations. The estimation of fracture radius for a glven tool size alds in evaluating costbeneflt tradeoffs. The program has been panticularly useful in demonstrating the need for larger tools at great depth and in large diameter casing. It also shows quantltatlvely the effect of such varlations as adding gas pressure at the surface to increase the hydrostatlc pressure at the tool, and provides a guide for using packers to reduce the gas volume lost in the casing. The FRAC program shows the effect of commonly used well flulds on the tamping action. The role of the gas generation time of the DGPL tool has been quantifled, and peak pressure estimates for formations which do not fracture can be made by adjusting the closure pressure until the iracture volume is zero and all the gas remains 
In the casing.

2-C. FRAC Program Oporation

The FRAC program provides a printed report of the calculation. The first section Identifles the well and the stimulation measured depth but none of the Identification data is used In the calculation. The second section describes the physical properties of the DGPL tool and the well. The third part of the report presents the calculated gas volumes, including the total gas volume and the casing gas volume, as well as the fracture volume and average fracture radlus. Some of the physical parameters of the model may be changed as requlred, Including the number of fracture wings, percentage heat retention, average tracture width, etc. A typlcal FRAC repont is shown in Figure 2-1. 


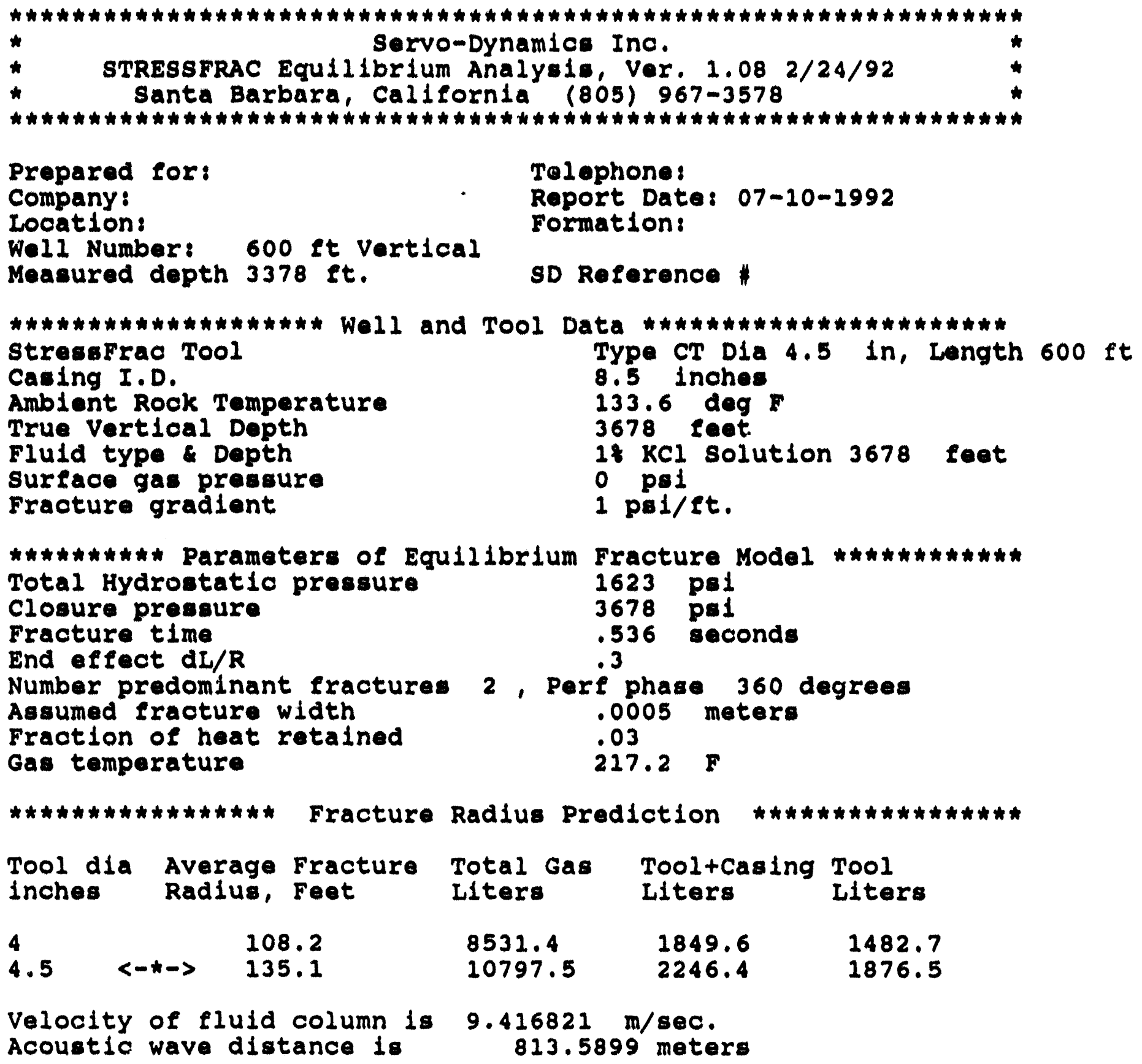

Figure 2-1 Sample FRAC Report 


\section{Digltal Data Recording Systems}

\section{3-a. Digitlzers and Computer Hardware}

The primary measurement undertaken was the pressure-time history of the DGPL gas generation process with one, two or three simultaneous pressure sensors. One channel is a stainless steel diaphragm/semiconductor strain gauge device from Omega which has DC respcinse capability, and the other two gauges are PCB Plezotronics plezoelectric pressure gauges with integral buffer circultry. The PCB gauges are capacitively coupled and can not read static pressure. Other interesting sensors have been considered, Including contact pins to measure the time of arrival of pressure or temperature changes at different points along the tool.

This project used economical standard computer components to construct high performance digital data acquisition systems. The laboratory system was a 486-33 generic IBM PC clone with a Model ADA-3100-3 analog and digltal I/O board from Real Time Devices in State College, PA. This board provides 12 bit conversion of 8 differentlal input channels with up to $200 \mathrm{KHz}$ throughput. The high data rate is made practical by an on-board FIFO (first in first out) buffer that holds the data when the computer is forced to take time to do other things.

A field portable system was assembled using a gasoline powered generator to produce 110 VAC $60 \mathrm{~Hz}$ power, and a generlc "Lunch Box" style computer using a clone IBM 48633 motherboard with LCD display and hard disk was purchased. This computer had two free expansion slots, one of which was used for the ADA-3100-3 I/O card. Thus all of the software and analog electronlcs could be used interchangeably on this system and the laboratory system.

\section{3-b. Software Design and Operation}

The custom MONITOR software for pulsed data recording was written under this DOE sponsored project using Microsoft Quickbasic ver 4.5. During data acquisition the computer is totally dedicated to moinitoring the data channels and recording data. The data is stored in two buffer areas within computer memory. The pre-shot buffer is circular, constantly re-writing over itself as the system walts for the shot it typlcally holds about 100 milliseconds of high speed data for 3 channels. When the pressure reaches a certain pre-defined trigger level on the selected trlgger channel, the program moves to the post shot buffer and stores another 100 to 3000 milliseconds of data for the three channels and one dlgital channel. Sampling rates as high as three channels of 30,000 samples per second per channel are practical. When the buffers are full, the data is written to the hard disk and then displayed on the screen. A series of menu screens allows the user to adjust the parameters of the system, which are stored in an ASCII setup file. The plezoelectrlc sensors are $A C$ coupled and require several minutes of settling time after power up before a shot, and so the program provides a monitor screen which shows the signal levels up to the time when data acquisition begins.

The MONITOR software has been used both for laboratory and fleld tests since the autotriggering on pressure data provides the simplest possible interface to the measured system. 


\section{Laboratory Cascade Chamber Studles}

\section{4-a. Differentlal Pressure Chamber Concept}

One of the interesting questions In the use of Dynamic Gas Pulse Loading is Just how much pressure is put on the well casing. Clearly if the casing is sealed, It must support the entire pressure, with the help of the surrounding cement and formation pressure. If the casing is heavily perforated, the gas and fluid are transmitted through the perforations and equalize the internal and external pressure. If the internal and external pressures are equal there is no tension in the casing. In practice, the system works well with rather limited perforations, down to about four $1 / 4$ inch dlameter holes per foot for the common 2 inch dlameter DGPL tools, though larger or more frequent perforations are preferred. Unfortunately, in a normal well it is not practlcal to measure the pressure outside the casing and so no fleld data has been obtained outside the casing, even though peak pressures inside the casing are measured with passive gauges on every stimulation.

The differentlal pressure chamber was deslgned to provide some laboratory data on the pressure transfer through a perforation. The test chamber is divided into two parts: a combustion chamber and an expansion chamber. There is a modular orifice between the two chambers and most work has been done with a 0.22 inch dlameter orifice. The expansion chamber is fitted with a small dlameter hydraullc plunger sealed with o-rings. This plunger simulates the formation of fractures. By using a copper shear pin, the "breakdown pressure of the formation" can be accurately controlled. After the pressure reaches the level required to shear the pin, the gas pressure drives the plunger out of the chamber. Welghts on the plunger simulate the mass of the fracture walls, though in these studles there is no restoring force on the plunger to simulate the closure pressure of the formation. Both the combustlon chamber and the expansion chamber are fitted with openings for pressure gauges, and usually the PCB Plezotronics plezoelectric gauges have been used to simultaneously record the pressure in both chambers. The burn rate and size of the propellant charge have been adjusted to simulate the peak pressure conditions in a well stimulation.

\section{4-b. Plezoelectric Sensor Techrology}

During initial experiments the combustion chamber was partly filled with water, leaving an air pocket above the water, with the test propellant mounted in a fitting on top. In order to reach higher pressures and more closely simulate actual field conditions, the volume of the alr pocket was reduced to almost nothing. Thls change resulted in sharper, higher Initlal pressure peaks at Ignition, and the plezoelectric gauges began to show high frequency oscillations with occasional dips below zero pressure later in the process. This unphysical result was puzzling. Eventually the gauges began to fall completely. Consultation with PCB led to the ldea that pressure waves reaching the threads of the gauge were compressing the plezoelectric element in three dimensions instoad of just on the end dlaphragm. To reduce the shock on the gauge body it was suggested that a small extension plpe and Tee fitting be used to isolate the gauge mount from shock, while maintaining contact with the fluid pressure. 
We considered using the more expensive 100,000 psi PCB gauges to avold damage, despite the loss of sensitlvity. However, satisfactory results are belng obtained with extension mountings for the 20,000 psl peak plezoelectrlc gauges. No higher pressure gauge has been purchased.

\section{4-c. Cascade Chamber Data}

Data for cascade tests 72 and 73 are presented on the following pages. The solld is the combustion chamber pressure while the dotted line is the expanslon chamber pressure. The second chart for each run shows the difference in pressure between the two chambers. The shear pin was set for a "hreakdown pressure" of about 5,000 psi in run \#72 and about 6,500 psi in run \#73. Note that the pressure in both chambers is almost equal during the rapld pressure rise, since the fluid in the chamber easily transmits the pressure through the perforation with very little fiow. Once the pin shears, simulating the opening of fractures, there is a substantial flow of gas through the perforation orifice. As the expansion chamber plston moves, the expansion chamber pressire drops rapidly. After about 10 milliseconds, the piston is completely outside the expansion chamber and the pressure drops to zero. With real fractures, fracture growth would slow as the gas pressure dropped to the closure pressure and then the flow would reverse, pushing the gas back into the well.

The Important conclusions of these experiments are that there is little difference in pressure between the inside and outside of the well casing during the Initial rapid rise of pressure. A difference of $10 \%$ to $20 \%$ of the peak pressure occurs during rapld gas flow into the fractures. These measurements confirm the experlence in thousands of wells that the DGPL process, with its properly controlled gas generation time, puts little stress on the well casing.

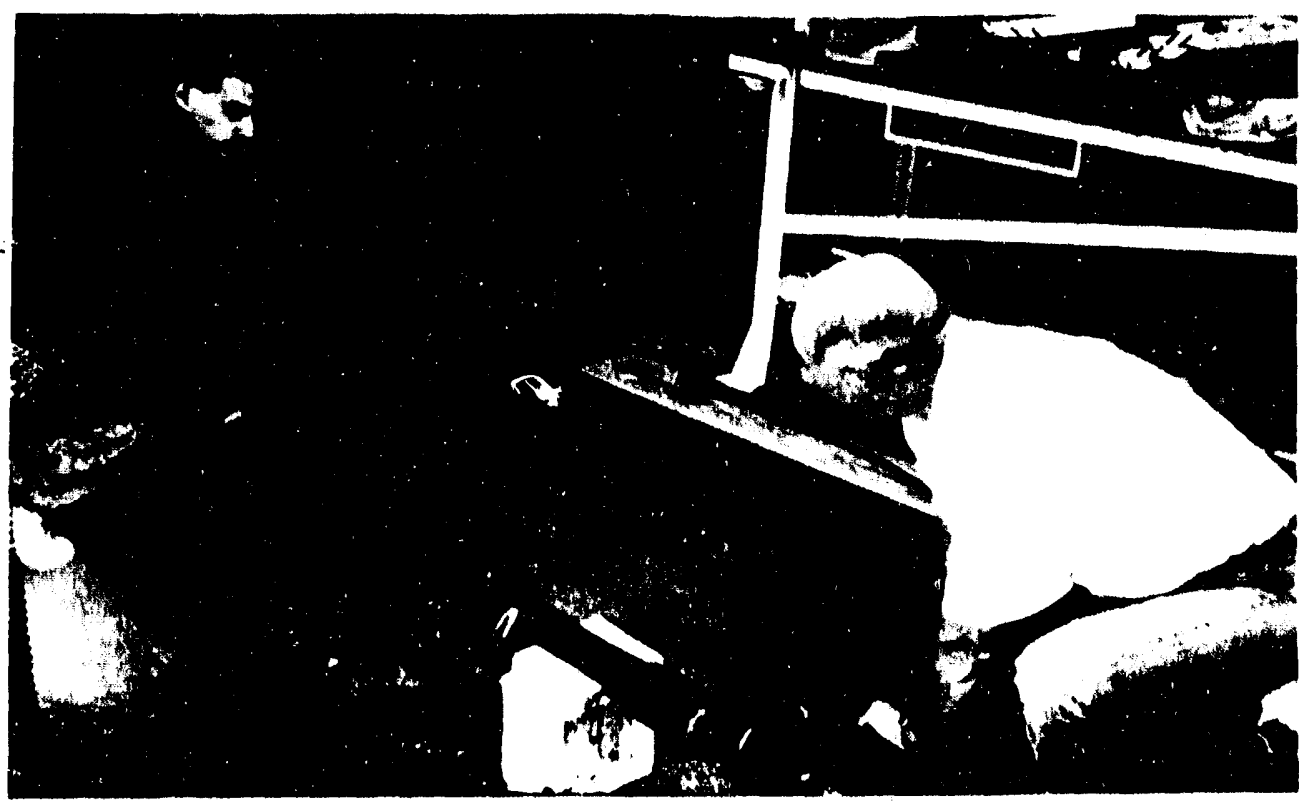

A test chamber is assembled at the Santa Barbara facllity. The hydraullc jack is used for gauge callibrations. 


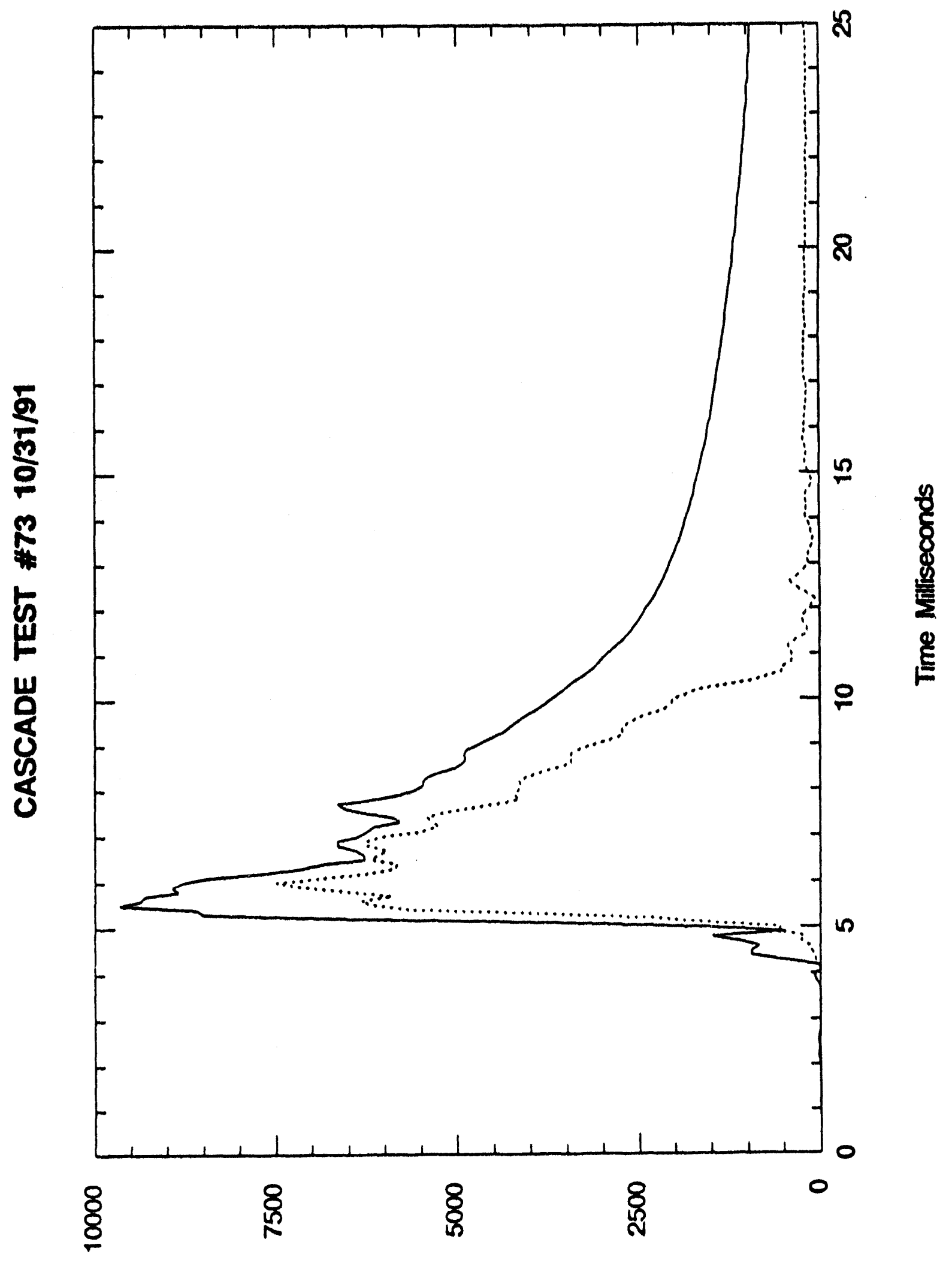

ISd ounssedd

Flgure 4-1 Cascade Chamber Pressure Measurement Test \#72 


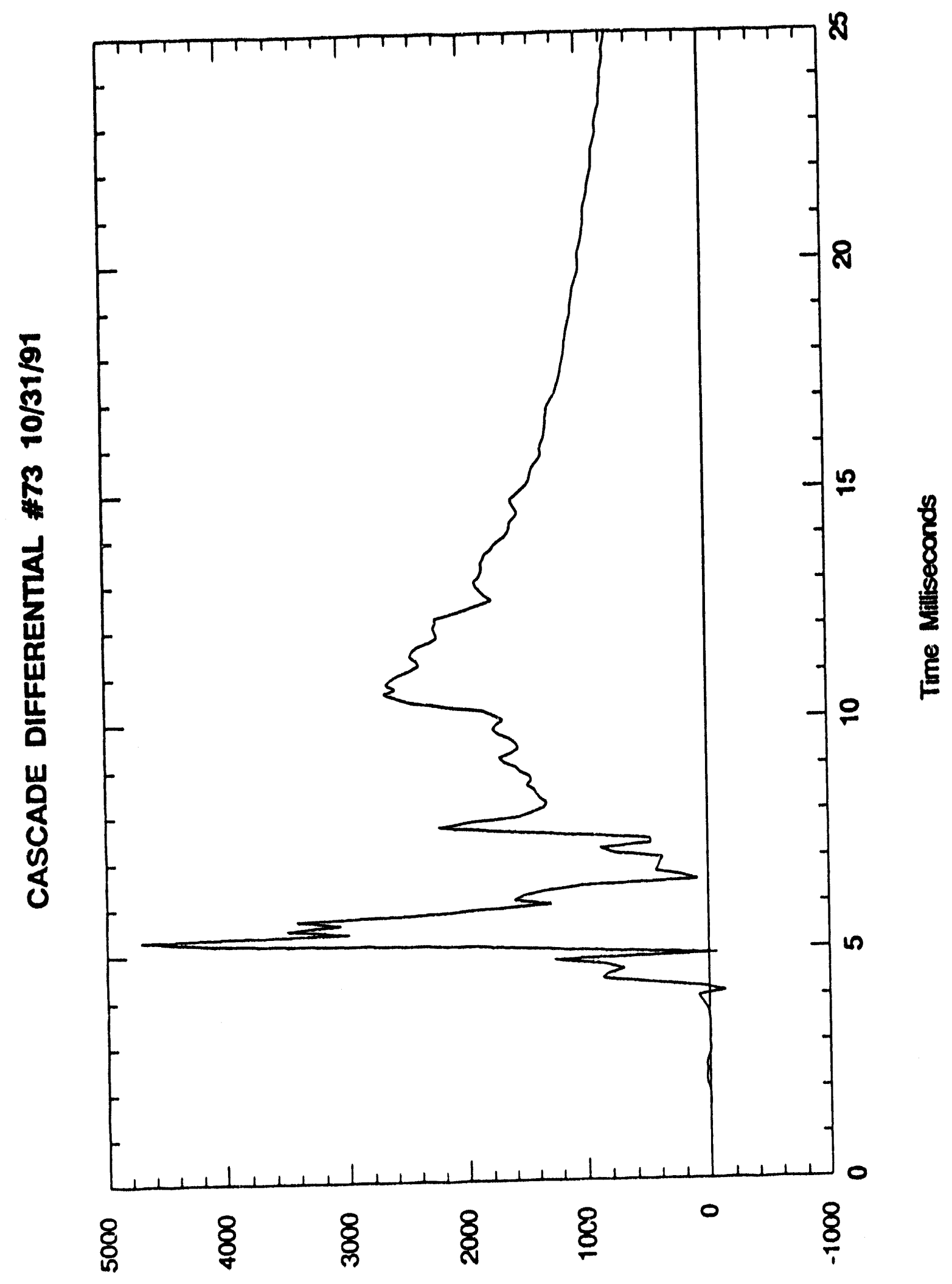

ISd ejnssajd IE!+uajaH!Q

Figure 4-2 Cascade Chamber Pressure Measurement Test \#72 Pressure Difference 


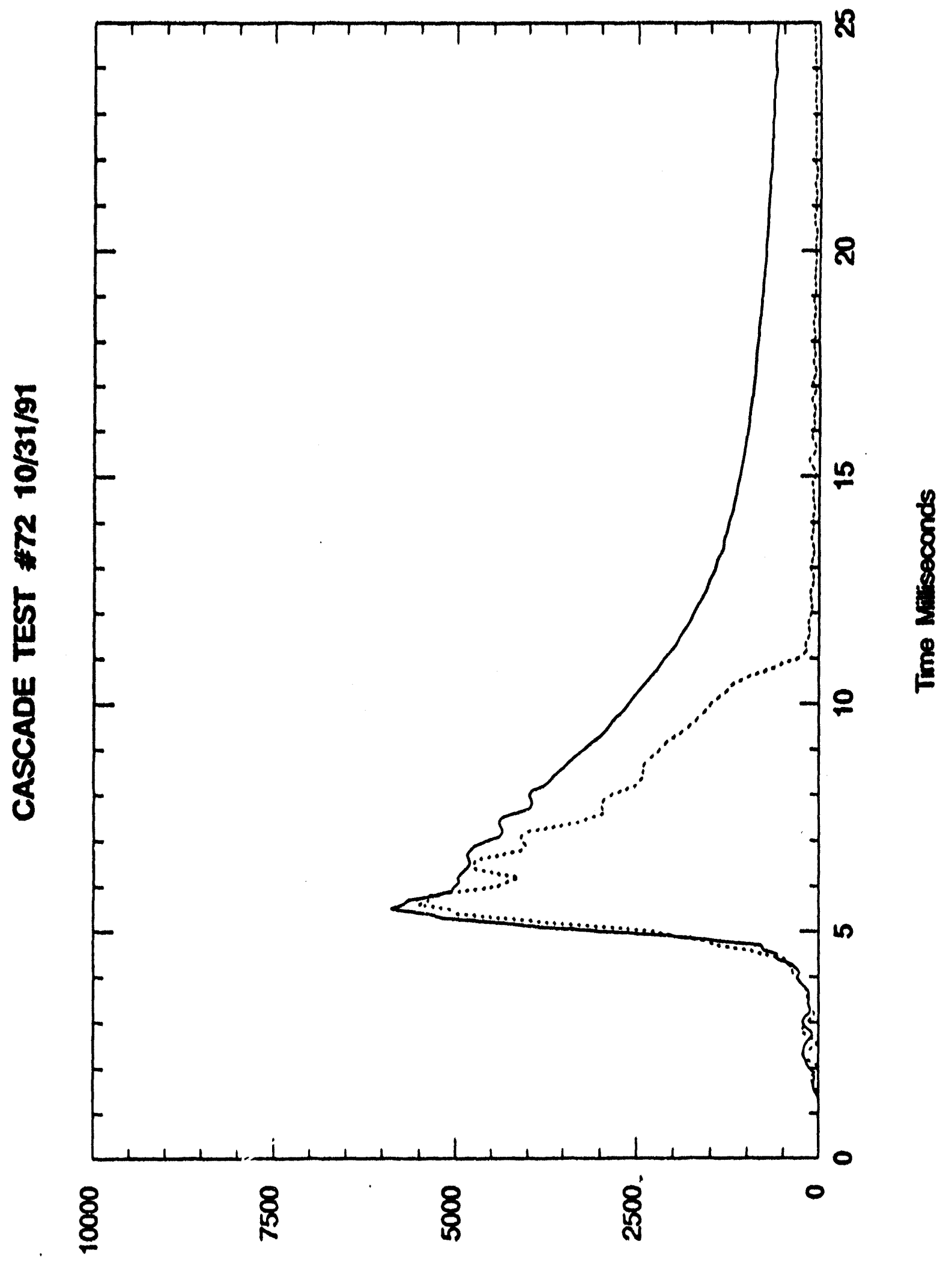

ISd esnesedd

Figure 4-3 Cascade Chamber Pressure Measurement Test \#73 


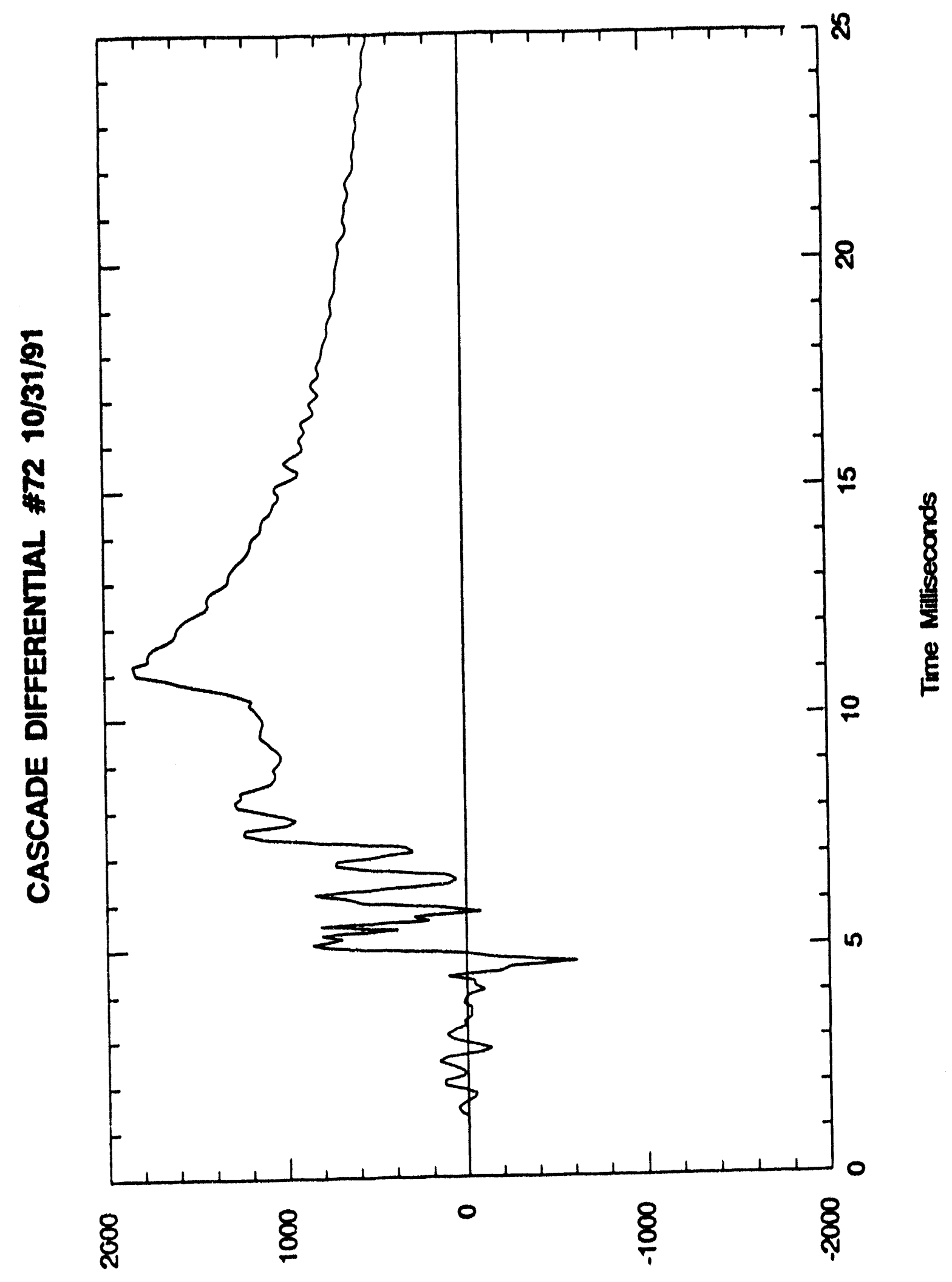

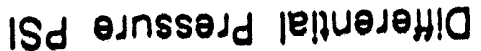

Figure 4-4 Cascade Chamber Pressure Measurement Test \#73 Pressure Difference 


\section{Marlcopa Fleld Studies}

\section{5-a Test Slte Facillitios}

Servo Dynamlcs has developed a fleld test area near Maricopa, CA to carry out fleld studies of the DQPL components. Figures 5-1 to 5-5 provide an overvlew of the test site and some of the test equipment. Pressure-time data for a burn rate test is shown in Flgure 5-6

\section{5-b Burn Rate Testo}

Fleld tests at the Servo-Dynamics Maricopa test site in the Tatt-Bakersfleld area:

Surface tests of the DGPL Ignition system and 1.25 inch diameter STRESSFRAC tools have been carried out at the fleld test site using our "lunch box" computer and digltal recorder system with a small gasolline powered generator. Important burn rate data was obtained with the digltal recorder. Excellent video images of the test were obtained using borrowed video equipment. One important result of the test is that we showed that unsupported ordinary J-55 $27 / 8$ inch dlameter tubing can withstand a peak pressure of $13,000 \mathrm{psi}$ without any damage or distortion. The rise time of the STRESSFRAC system is slow enough that it does not shock the material, and brief enough that it does not fatigue it. In actual downhole applications the well casing is supported by the pressure of the surrounding formation and much higher pressures can used safely because the net pressure on the casing is reduced by pressure transfer through the perforations.

The burn rate of propellant materlals tends to be pressure sensitive. Higher pressure or temperature tends to produce more rapld gas generation. In fact, the Stressfrac tool material in the open air is quite difficult to lgnite with a flame, and is far safer than gasoline. For some materlals, not used by Servo Dynamics, this pressure sensitivity can lead to a low grade detonation which is very destructive. The DGPL system has been designed to perform rellably under a wide range of environments Including high and low pressure, high and low remperature. However, continued study of the detalled performance of the system under different pressure conditions will lead to a quantitative understanding that can be used to enhance the effectiveness of the tool under extreme conditions. 


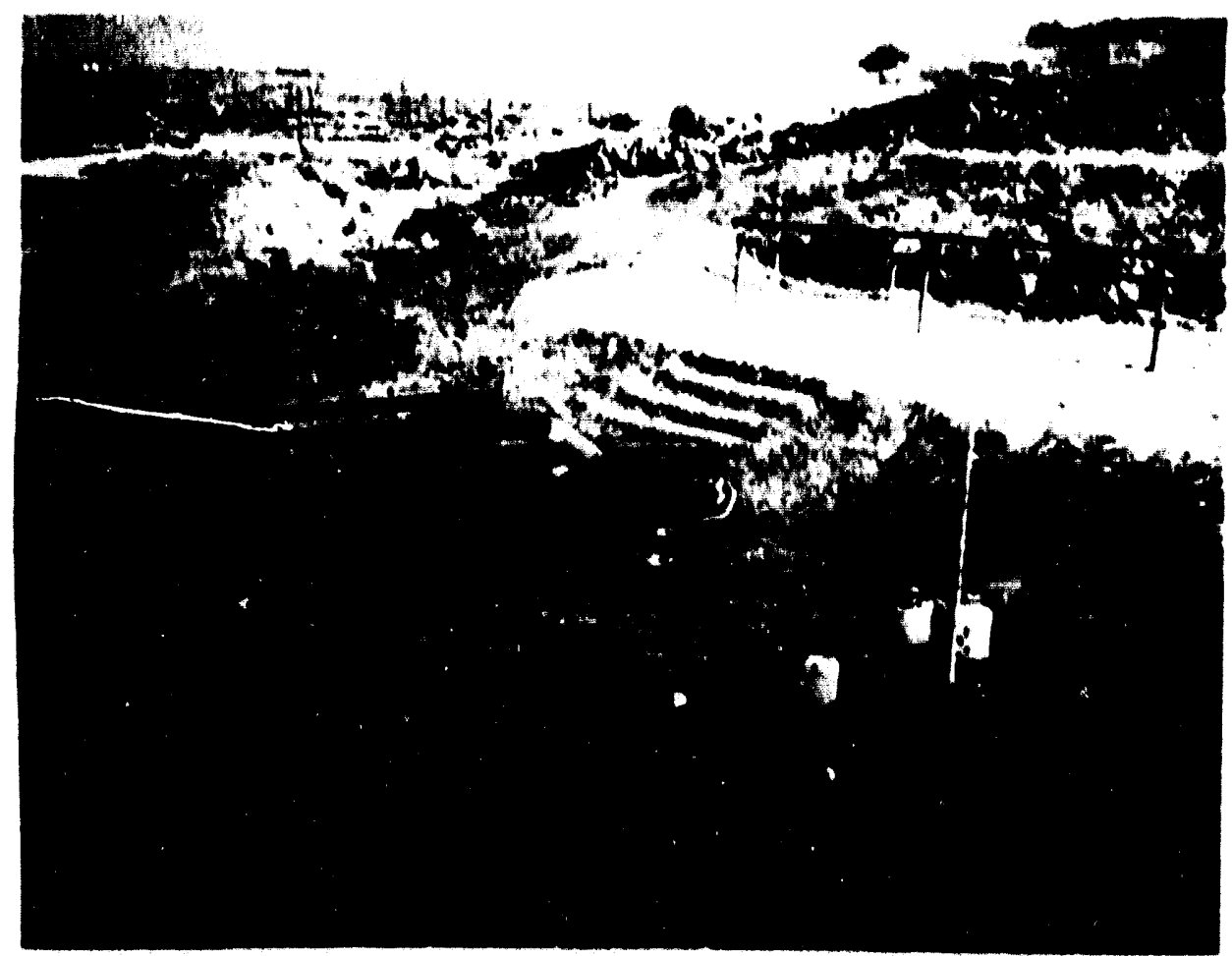

Figure 5-1 An overview of half of the small valley cocupled by the test faclity showe the setup for a vertical test of $1 / 4$ Inch DGPL in the foreground and horizontal raoks in the background where Stresstrac tools are tested.

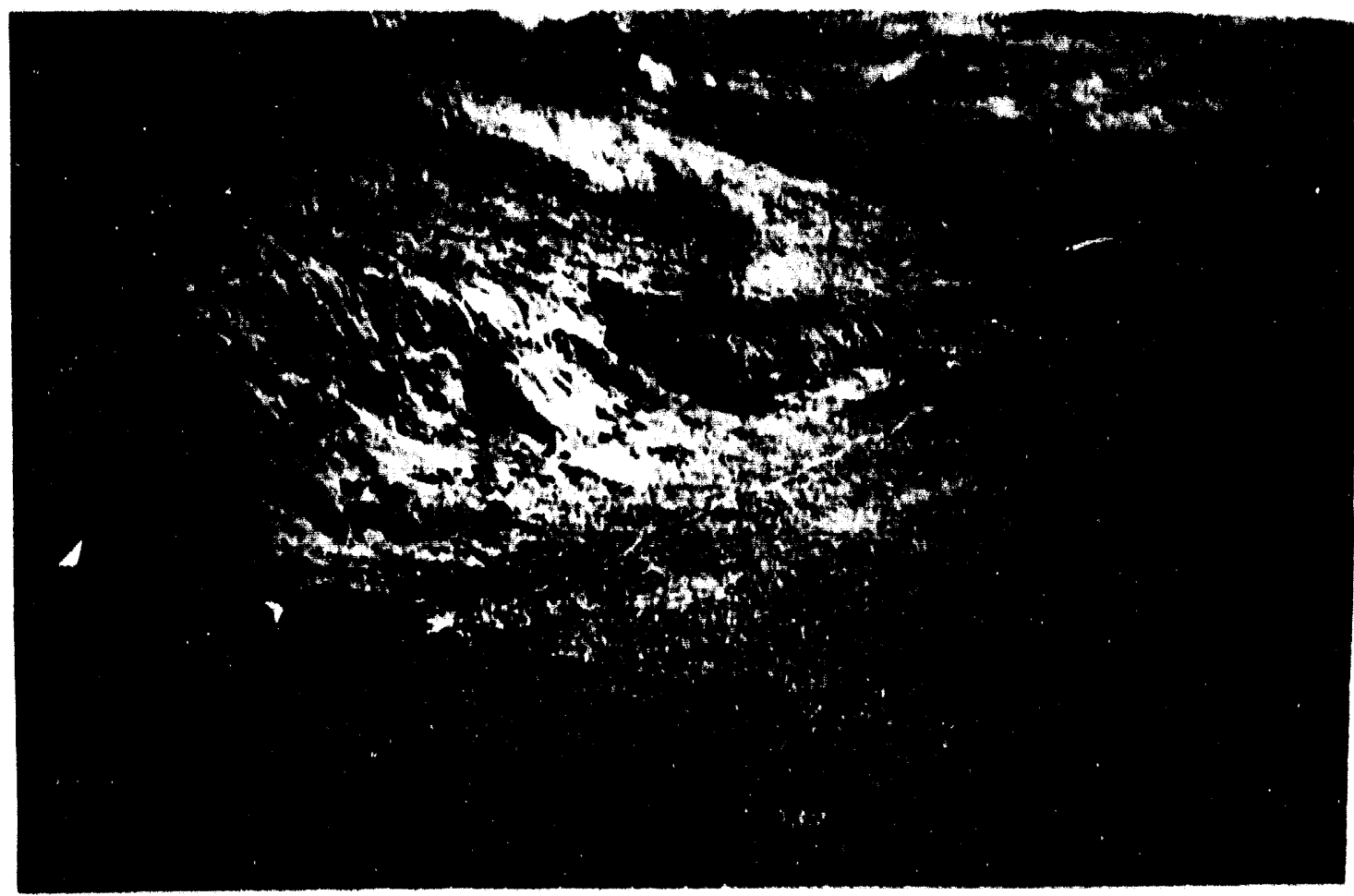

Figure 5-2 A gasoline powered generator supplles 110 volt AC power for the "Lunch Box" recorder system and ampliflers. 


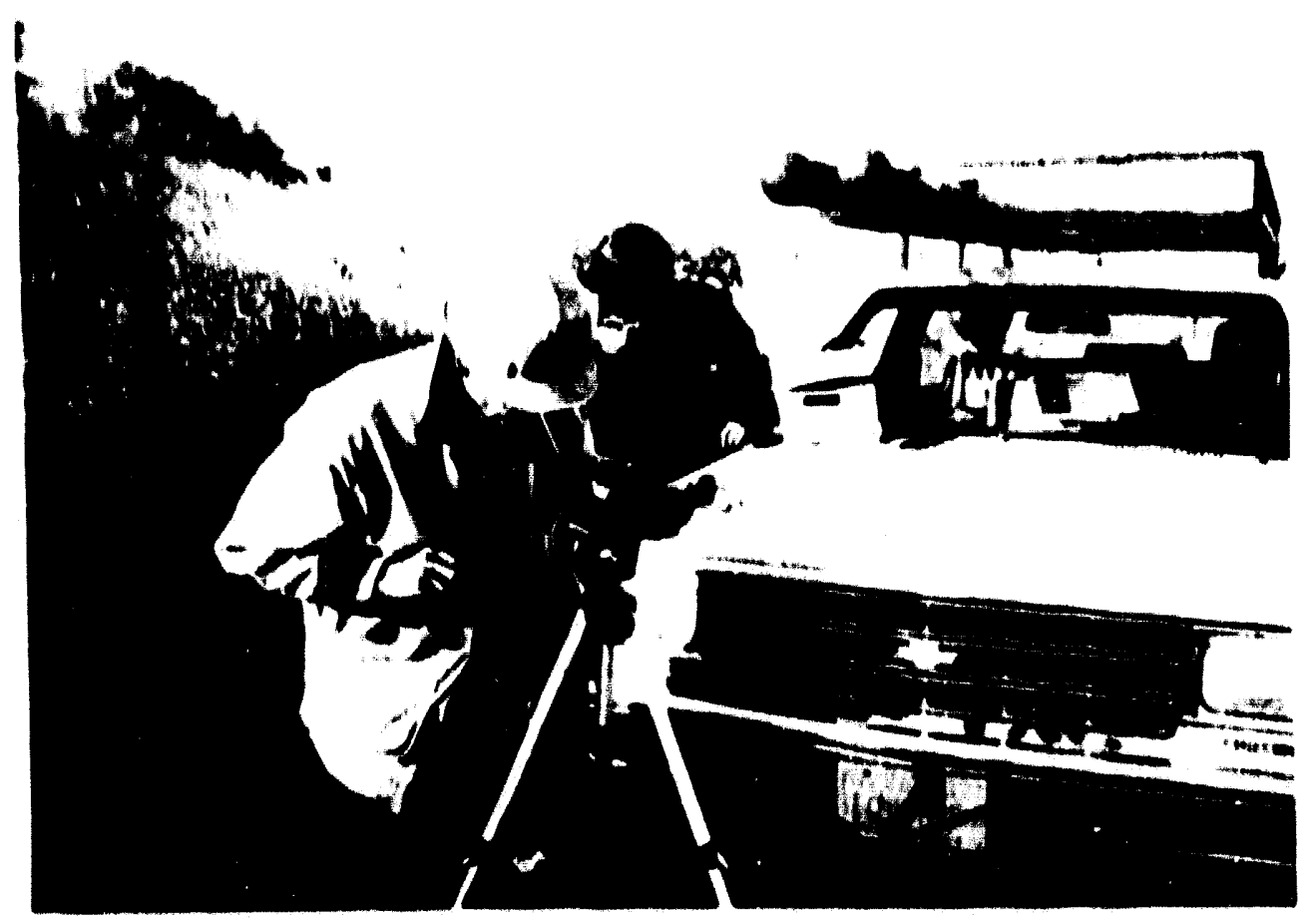

Figure 5-3 A video recorder with high speed frame capture was used to photograph the tests from the other side of the valley.

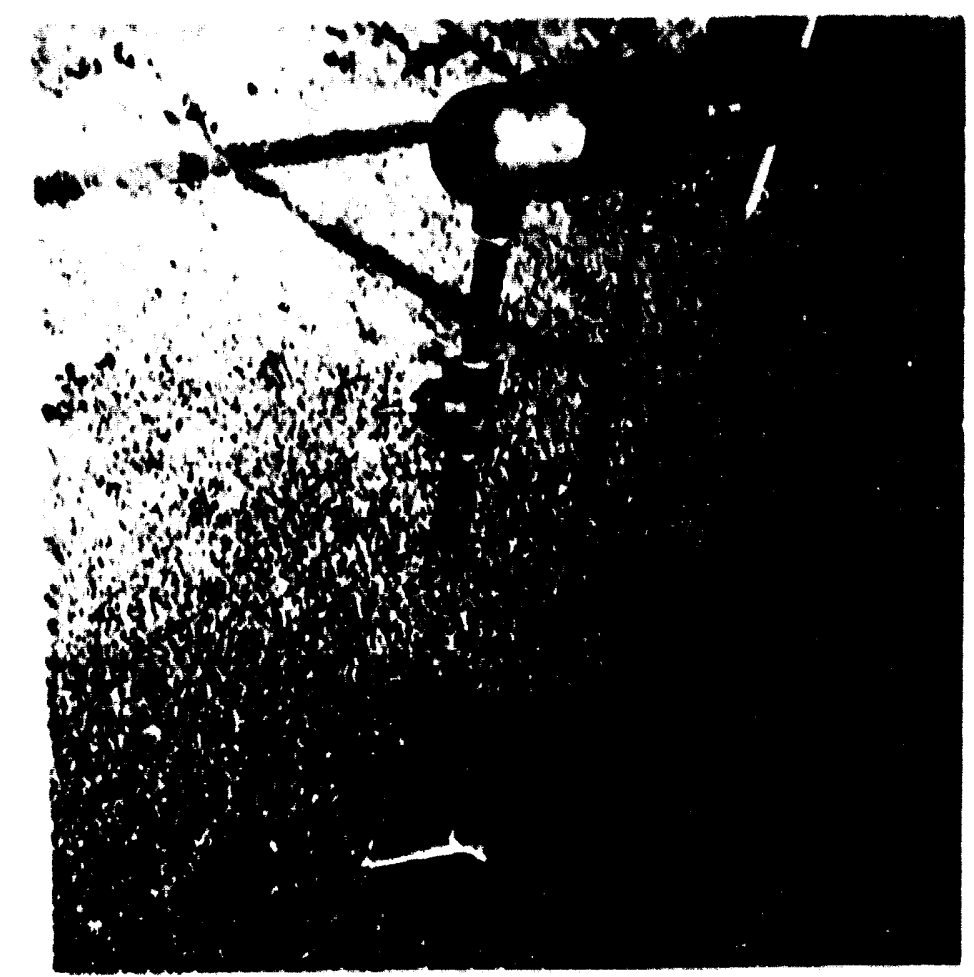

Figure 5.4 The PCB Plezotronics sensor has been mounted on a short stub of plpe filled with water at the end of the test chamber. Data is shown In Figure 5-6. 


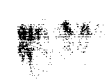

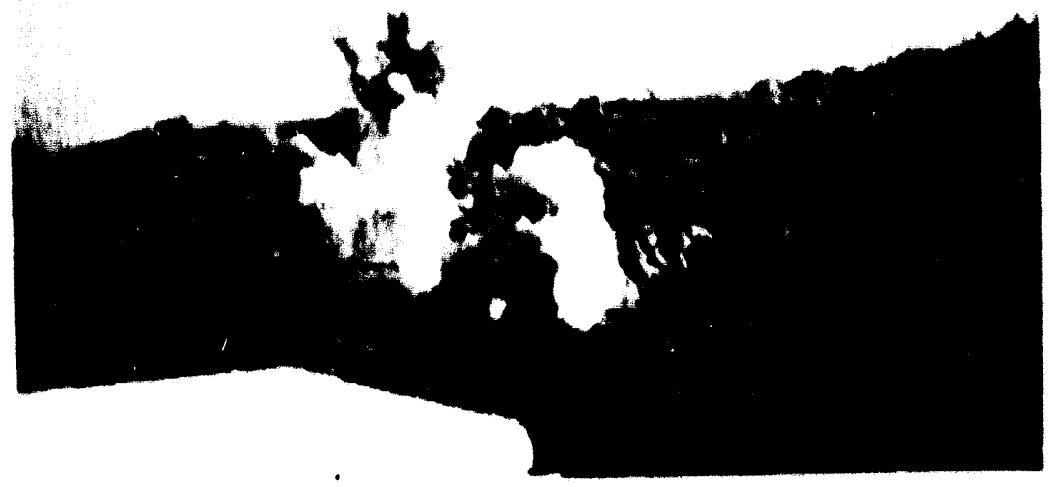

Figure 5.5 This 35mm photo shows the smoke cloud rising from the 1.25 inch Stressfrac tool test. Video data not shown here provided time resolved Images of the gas production. Pressure data from this test is shown in Figure 5-6. 


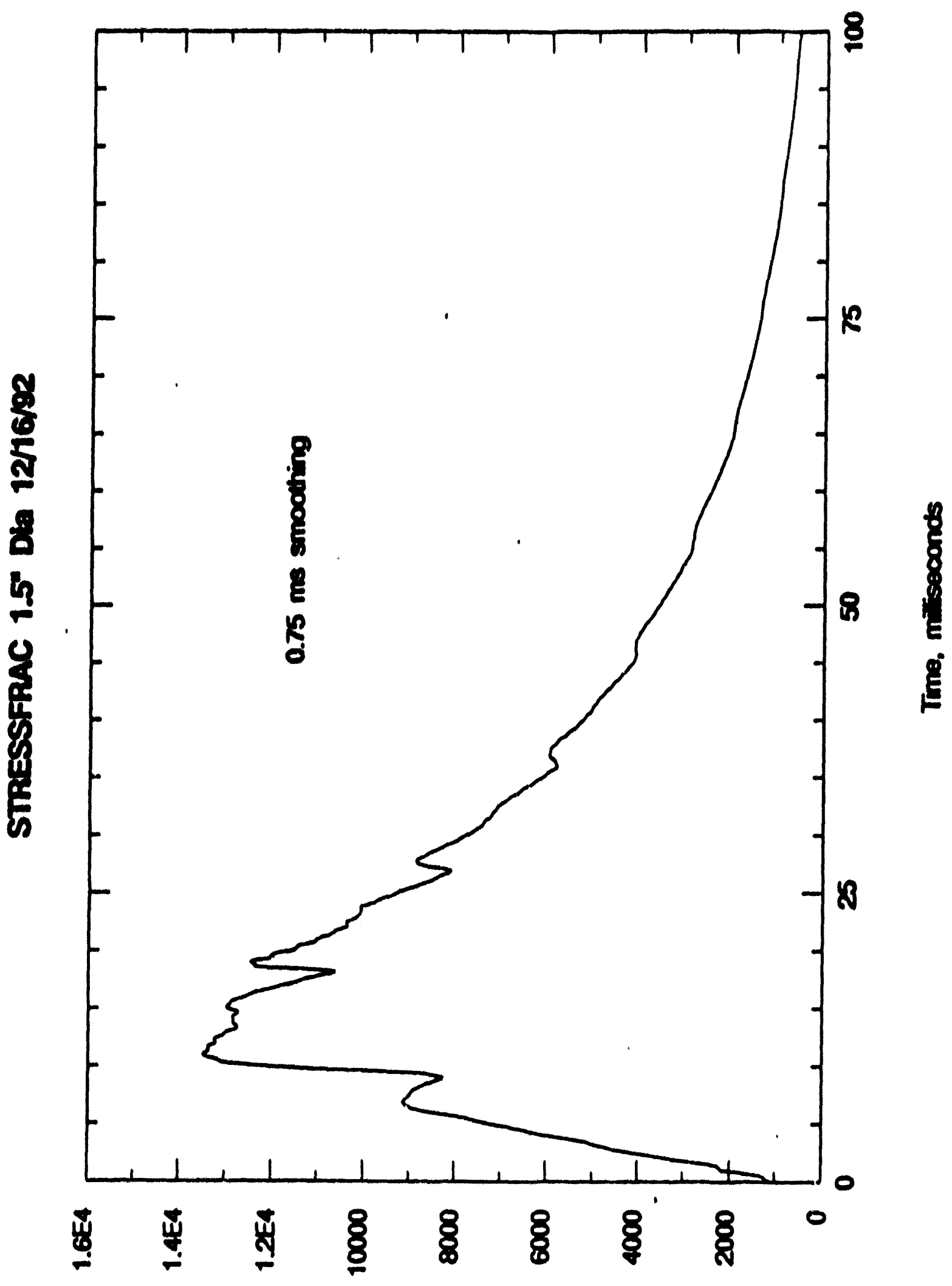

led 'odnseodd

Figure 5-6. Pressure time curve recorded for 1.25 inch dla Stressfrac tool, In alr, enclosed by $27 / 8$ inch diameter tubing with four $1 / 4$ inch dla holes every 2 foet. 


\section{Downhole Presaure Mosasurement Technlques}

\section{8-a. Wirollne with Pressure or contact Ignition}

\section{Downhole Presesure Moasurement}

A new development will allow the existing fleld digital recording system for pressure measurements to be used for downhole measurement in wells of moderate depth. The recording system was orlginally concelved for use with wireline tools, and almost all of our recent work has been with tubling conveyed systems. The most common trigger method for tubing conveyed stimulations is to pressurlze a continuous length of tubing running from the tool to the surface. After the tool is placed at the desired depth, a surtace pump is used to increase the pressure and irlgger the stimulation. Thls system does not lend Itself to the use of a local pressure gauge with a coaxial cable to the surface, since it is difficult to place the cable in the pressurlzed tubing, and the tubing lsolates the sensor from the pressure in the well casing. However, an alternate system has been designed In which the tubing above the tool is pertorated to allow communication of the wellbore pressure. An alternative trigger method must be used in which a drop bar or "go-devil" is attached to the signal cable and contains the pressure sensor. Contact between the drop bar and the Ignition mechanism at the top of the tool would Initiate gas generation. Thls system has not yet been tested but it promises to be conventent for wells of less than 5000 feot depth.

\section{6-b. Wireline with Electrical Ignition}

The standard coaxlel wireline has only two electrical paths, the center wire and the return path of the shield. The shield is treated as an electrlcal ground. Thus the problem becomes one of sharing the center conductor between an electrical lgnition circult and the pressure sensor. The pressure sensor requires a constant current of 5 to 20 milliamps at a voltage of about 10 volts for a perlod of several minutes before the measurement to stabilize the output which is coupled through a large capacitor. The dynamic transducer output impedance is approximately $100 \mathrm{ohms}$. The Ignition system is simllar to a flashlight fllament, and requires 250 milliamps at 6 volts. A circult has been developed to store energy in a capaclior located near the sensor, and coupled to the sensor with a large value resistor which the sensor can easily drive during the measurement. The tool 18 assembled and installed with the cable shorted out. Then when It is in position, the transducer power is applled and the data recording system is activated. The energy storage capacitor slowly charges over a period of several minutes during which time the sensor stabillzes. Attached to the energy storage capacitor is a sensitive gate SCR transistor which connects the capacitor to the lgnition element. A voltage sensing clrcult triggers the SCR when the capacitor voltage reaches 7 volts, operating the lgnitor and triggering the gas generator. Although thls clrcult has been breadboarded and tested it has not been used because most recent work has used tubing conveyed tools instead of wirellne. 
6-0. Downhole recording syatems

A downhole recording system has been developed for other DOE applicatlons by SAIC of Las Vegas, Nevada, and has seen IImited use In gas fracturing silmulatlons by other firms. This system was a self contained unlt with battery power that recorded and stored the pressure data which was then read out into a computer after the recorder was retrleved from the well. The original design is no longer offered commerclally for gas fracturing because of a high fallure rate in this application. The combination of high temperature and enock presents a difflcult environment for electronlos. However, SAIC has expressed interest in updating the design to a new highly ruggedized version. The quoted cost of the design update and a minimum order of recorders exceeds the total funding of thls grant.

A limited inveatlgation of commerclally avallable mlcroprocessors systems was carrled out in an effort to locate an off-the-shelf system that could be adapted to thls application. Small mlcroprocessor boards by Dallas Semlconductor and Now Mlcros Inc. Were examined for this application. The Now Mlcros board uses the Motorola 68HC11, one of several microprocessors which incorporate an elght blt analog to digltal converter. We also considered an external 12 bit converter which offered higher speed and accuracy at the cost of more power consumption and complexity. These mlcroprocessor boards are small, but they are not designed to flt inside a 1 inch plpel By the time an appropriate housing surrounds them, the unit would be limited to relatively large wellbores. The mechanlcal shock and temperature limltations are certainly inferlor to the SAIC system. so that use would be restricted to shallow wells and small stimulations. Though the use of a down-hole recorder ls a promlsing optlon for the future, because of limited time and IImited funds our development of thls concept has been temporarlly halted in favor of the sensor and cable approach. 


\section{Acoustlc and Solsmic Measurements}

\section{7-a. Sensors and recording equipment}

Two naw types of measurement were attempted for the first time for DGPL stimulations under thls program. The first was acoustic measurement of sounds carried by the well casing, and the second was selsmic measurement of vibrations carried by the earth.

Even In a large stimulation like the South Mountain Job described in section 1 where two truckloads of Stressfrac tool were used, the workers at the surface did not hear anything during the stimulation. However, by attaching a contact mlcrophone to the well casing and recording the sound with a battery powered stereo cassette recorder, an Interesting sonic record was obtained. The sound carrled to the surface by the casing resembled distant thunder which continued for several seconds. There were discrete audible events which may be related to fracture formation or may be due to bursts in gas generation. This data record provides useful additional data, not the least of which to assure the crew that the stimulation has in fact ocsurred. Later, the effect of stimulation was obvlous as natural gas pressures rose to levels that had not been observed for $\mathbf{3 0}$ years.

The experimental seismic sensor was constructed by welghting the speaker cone of a 3 inch budspeaker with a large steel washer, and sandwiching the speaker between two buards. Vibration of the boards moves the speaker, and the heavy weight of the speaker cone causes it to lag behind, which causes the drive coll of the speaker to meve in the speaker magnet and generate an electrical signal. This simple and economical sensor was connected directly to the second microphone input of the stereo recorder. The resulting traces are quite interesting, and seem to show a serles of selsmic shocks correspondinc te fracture formation. Some of these shocks occur some seconds after the onset of stimulation, and suggest that fractures continue to grow due to in situ stresses even as the gas pressure is dropping. A chant recording of the signal envelope for acoustic and seismic signals in the South Mountain stimulation is shown In Figure 6-1.

\section{7-b. Acoustic and Selsmlc Data}

\section{Seismic Measurements}

iir the recent North Dakota test the first stimulation showed higher peak pressures than the secorid, indicating that the non-producing iormation was more difficult to fracture. The seismlc geophone measurements at the surface were qualltatively different on these two stimulations. The high-pressure, non-producing formatlon produced about $\mathbf{3 0}$ small and rapid seismic signals, while the low-pressure producing formation produced about 5 large selsmic signals. The difference in number, amplitude and frequency of the seismic signals suggests that we are measuring qualitatively different fracture processes in these two regions of the same well. The duration of the selsmic signals was longer than the expected burn time of the tool, which suggests that the selsmic signals may be generated as the gas cools and the formation shifts back to a new equillbrium position. This shifting process may be powered by pre-existing strain in the formation and may supply additional energy to extend the fractures. This very preliminary data suggest that the selsmic 
measurements may have considerable value, though much additional study is needed. The use of precision accelerometers In a three dimensional vector conflguratlon together with accurately timed recoroing of motion at several surface locations may provide a much more complete ploture of the fracture process.

The acoustlc and selsmic measurements were repeated with interesting results in two successive stimulations of a horizontal well in North Dakota. These stimulations used Stressfrac tools of about 100 feet in length. The first stimulation was in a very tight formation at the end of the well which lead to relatively high peak pressures, $10,000 \mathrm{ps}$ l over statlc pressure, on the passive pressure gauges. The selsmic record of that stimulation showed a tlght nest of small selsmic events, suggesting short locallzed fractures Immedlately around the wellbore. The second stimulation was in a producing zone about 1000 feet from the end of the well. This time the peak pressure readings were lower, 4,000 psl over static pressure, In line with the expected breakdown pressure of the formation. The selsmic record in this case showed a smaller number of large selsmic events, as though the gas was able to extend each fracture a considerable distance before inltiating a new fracture. 


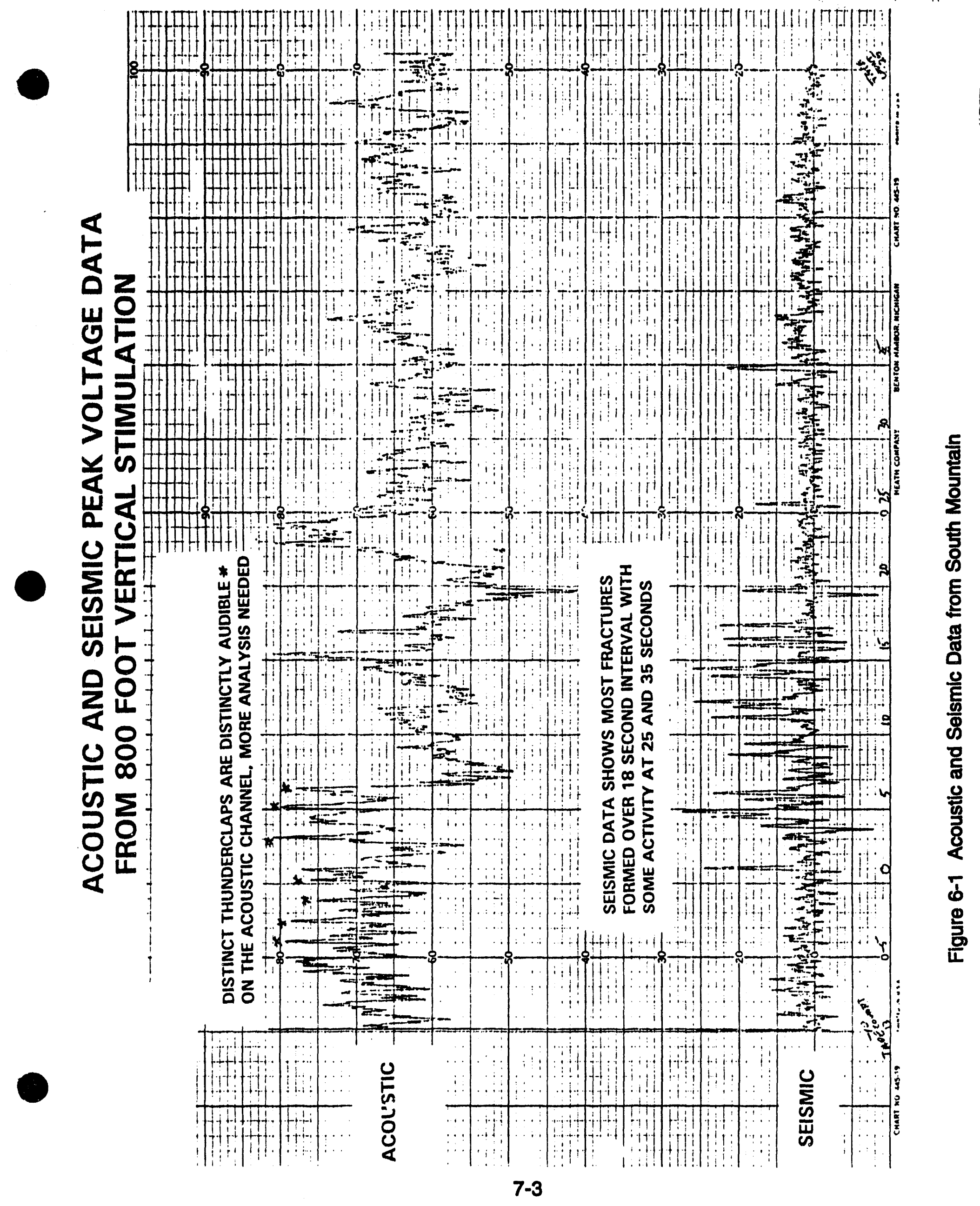



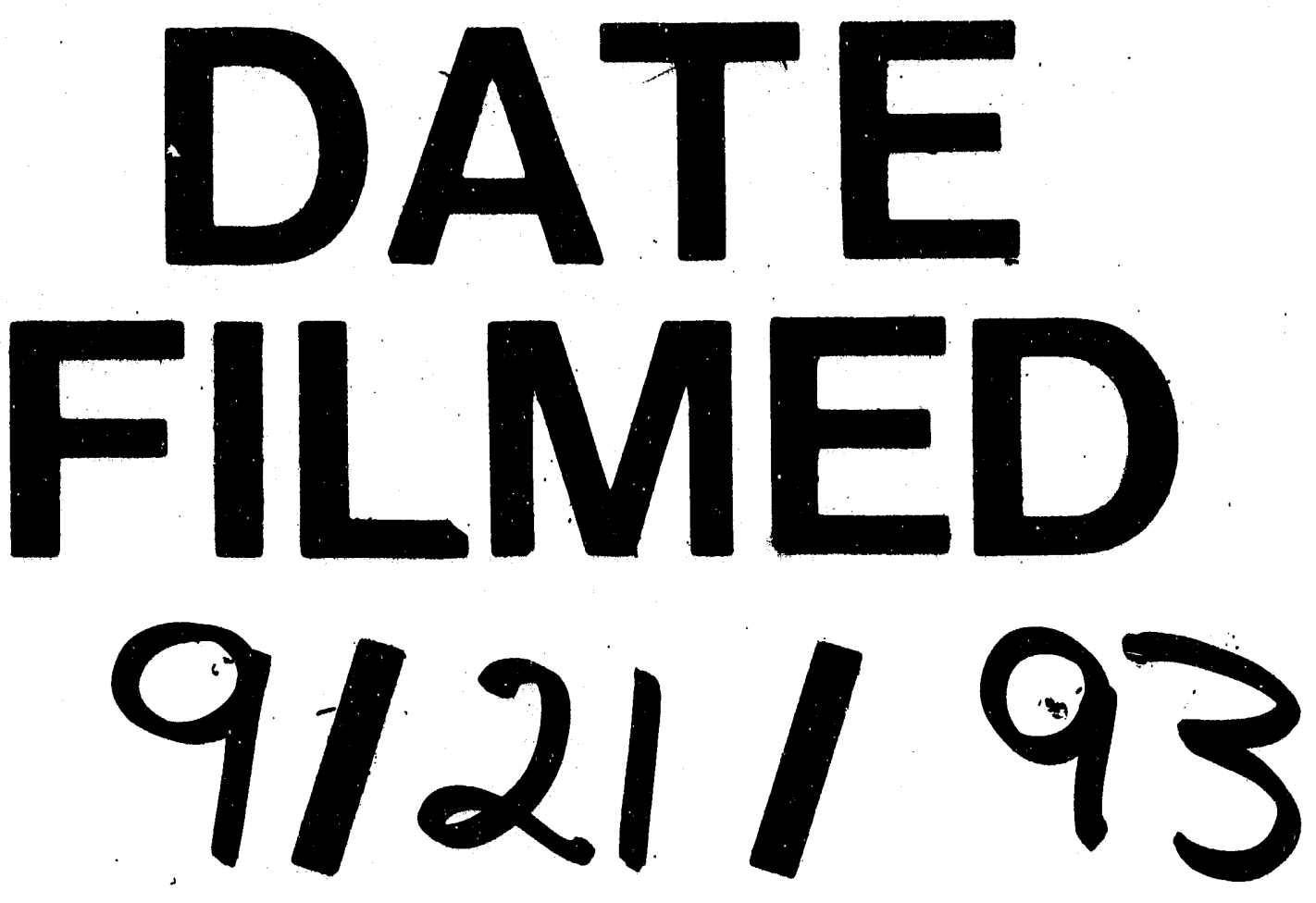


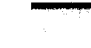

